\title{
Cellular distribution of vascular endothelial growth factor $A$ (VEGFA) and B (VEGFB) and VEGF receptors 1 and 2 in focal cortical dysplasia type IIB
}

\author{
Karin Boer · Dirk Troost • Wim G. M. Spliet • \\ Peter C. van Rijen · Jan A. Gorter · Eleonora Aronica
}

Received: 28 November 2007 / Revised: 18 February 2008 / Accepted: 18 February 2008 / Published online: 4 March 2008

(C) The Author(s) 2008

\begin{abstract}
Members of the vascular endothelial growth factor (VEGF) family are key signaling proteins in the induction and regulation of angiogenesis, both during development and in pathological conditions. However, signaling mediated through VEGF family proteins and their receptors has recently been shown to have direct effects on neurons and glial cells. In the present study, we immunocytochemically investigated the expression and cellular distribution of VEGFA, VEGFB, and their associated receptors (VEGFR-1 and VEGFR-2) in focal cortical dysplasia (FCD) type IIB from patients with medically intractable epilepsy. Histologically normal temporal cortex and perilesional regions displayed neuronal immunoreactivity (IR) for VEGFA, VEGFB, and VEGF receptors (VEGFR-1 and
\end{abstract}

K. Boer $\cdot$ D. Troost $\cdot$ E. Aronica $(\bowtie)$

Department of (Neuro) Pathology,

Academic Medical Center, University of Amsterdam,

Meibergdreef 9, 1105 AZ Amsterdam, The Netherlands

e-mail: e.aronica@amc.uva.nl

W. G. M. Spliet

Department of Pathology,

University Medical Center Utrecht,

Utrecht, The Netherlands

P. C. van Rijen

Department of Neurosurgery, Rudolf Magnus Institute for Neuroscience, University Medical Center Utrecht, Utrecht, The Netherlands

J. A. Gorter · E. Aronica

Stichting Epilepsie Instellingen Nederland,

Heemstede, The Netherlands

\section{J. A. Gorter}

Swammerdam Institute for Life Sciences,

Center for Neuroscience, University of Amsterdam,

Amsterdam, The Netherlands
VEGFR-2), mainly in pyramidal neurons. Weak IR was observed in blood vessels and there was no notable glial IR within the grey and white matter. In all FCD specimens, VEGFA, VEGFB, and both VEGF receptors were highly expressed in dysplastic neurons. IR in astroglial and balloon cells was observed for VEGFA and its receptors. VEGFR-1 displayed strong endothelial staining in FCD. Double-labeling also showed expression of VEGFA, VEGFB and VEGFR-1 in cells of the microglia/macrophage lineage. The neuronal expression of both VEGFA and VEGFB, together with their specific receptors in FCD, suggests autocrine/paracrine effects on dysplastic neurons. These autocrine/paracrine effects could play a role in the development of FCD, preventing the death of abnormal neuronal cells. In addition, the expression of VEGFA and its receptors in glial cells within the dysplastic cortex indicates that VEGF-mediated signaling could contribute to astroglial activation and associated inflammatory reactions.

Keywords Vascular endothelial growth factor .

Receptors · Dysplastic neurons · Astrocytes ·

Immunocytochemistry $\cdot$ Epilepsy

\section{Introduction}

The vascular endothelial growth factor (VEGF) family includes seven members which are structurally homologous, but display molecular and functional diversity [58, 81]. VEGFA, the most well known member of the VEGF family, is a crucial regulator of angiogenesis and vascular permeability in both physiological and pathological conditions such as tumor growth, chronic inflammation, and ischemia $[10,16,19]$. In addition to the unquestioned role in angiogenesis, it has recently been shown that VEGFA 
has direct trophic effects on neuronal and glial cells in the central nervous system [10, 22, 25, 53].

VEGFB is most closely related to VEGFA [46, 81]; however, the biological function of VEGFB is less well characterized than the function of VEGFA. VEGFB is expressed early during development and appears to have prominent expression in the central nervous system $[1,36]$. Additionally, VEGFB has been shown to function as an angiogenic and neuroprotective protein $[29,63,68]$ and recent evidence suggests a role for VEGFB in neurogenesis [69, 70].

The diverse functions of VEGF proteins can be explained by their differential binding to signaling VEGF receptors [VEGFRs; VEGFR-1 (Flt-1), VEGFR-2 (Flk1/ KDR), and VEGFR-3 (Flt-4) [50, 81]]. VEGFA binds to VEGFR-1 and VEGFR-2, whereas VEGFB binds specifically to VEGFR-1 and not to VEGFR-2 [81].

The VEGF-signaling pathway, involving both neuronal and glial cells, has been implicated in several neurological disorders, including neurodegeneration, stroke, and cerebral and spinal trauma [10]. In addition, expression of VEGFA is upregulated in neuronal and glial cells after epileptic seizures in rats [13], suggesting a role for VEGFA in seizure disorders. A recent study points to a neuroprotective role for VEGFA following status epilepticus [45]. The relevance of these findings in animal models to human epileptic disorders is uncertain. Using serial analysis of gene expression (SAGE), we recently identified the VEGFB gene to be upregulated in human tissue from a patient with focal cortical dysplasia (FCD) and intractable epilepsy compared to control cortex (Boer et al., unpublished observations). Upregulation of VEGFA and its receptor has also been recently shown in the hippocampus of cases of human temporal lobe epilepsy (TLE) [56]. However, the distribution of VEGFA, VEGFB, and VEGFRs in epilepsy-associated human malformations of cortical development has not yet been defined.

In the present study, we investigated the expression of both VEGFA and VEGFB and their receptors (VEGFR-1 and VEGFR-2) in patients with FCD, which is a developmental disorder known to be a major cause of intractable epilepsy [73]. We report the specific cellular distribution, including both the neuronal and the glial components of the dysplastic cortex, and we discuss the potential role of VEGFA, VEGFB, and their receptors in the histogenesis and epileptogenesis of this developmental lesion.

\section{Materials and methods}

Subjects

The cases included in this study were obtained from the databases of the Departments of Neuropathology of the
Academic Medical Center (University of Amsterdam; UVA) in Amsterdam and the University Medical Center in Utrecht (UMCU). We examined surgically resected tissue from nine patients undergoing epilepsy surgery for focal cortical dysplasia. Informed consent was obtained for the use of brain tissue and for access to medical records for research purposes. The tissue was obtained and used in a manner compliant with the Declaration of Helsinki.

The classification system proposed by Palmini et al. [48] was used for grading the degree of FCD and only patients with FCD type IIB located in the temporal lobe were included. The clinical characteristics derived from the patient's medical records are summarized in Table 1. The predominant type of seizure pattern was that of complex partial seizures, which were resistant to maximal doses of antiepileptic drugs (AEDs; carbamazepine, valproic acid, phenytoin, levetiracetam, oxcarbazepine, and clonazepam). Information concerning the exact time of last seizure occurrence prior to surgical resection was not available. However, all the patients included in our series did not have seizure activity in the last $24 \mathrm{~h}$ before surgery. The patients underwent presurgical evaluation [74]. Intraoperative ECoG was performed routinely in all operations for tailoring of surgery and we classified the post-operative seizure outcome according to Engel [17]. Follow-up period ranged from 1 to 9 years.

Normal-appearing control cortex/white matter from temporal region was obtained at autopsy from five adult control patients (male/female: $2 / 3$; mean age 42 , range 17-55) without history of neurological diseases. All autopsies were performed within $12 \mathrm{~h}$ after death (post mortem delay: 11, $11.5,9,8.5,6$ ). The cause of death was represented by acute myocardial infarction. In addition, four of the nine FCD cases contained sufficient amount of perilesional zone (normal-appearing cortex/white matter adjacent to the lesion), for comparison with the autopsy specimens. This

Table 1 Summary of clinical findings of patients with focal cortical dysplasia

\begin{tabular}{lllll}
\hline $\begin{array}{l}\text { Patient/sex/ } \\
\text { age (years) }\end{array}$ & Diagnosis & $\begin{array}{l}\text { Duration of } \\
\text { epilepsy (years) }\end{array}$ & $\begin{array}{l}\text { Seizure } \\
\text { type }\end{array}$ & $\begin{array}{l}\text { Engel } \\
\text { class }\end{array}$ \\
\hline 1/M/11 & FCD IIB & 11 & CPS & I \\
$2 / \mathrm{M} / 31$ & FCD IIB & 20 & CPS & I \\
$3 / F / 25$ & FCD IIB & 9 & CPS & I \\
4/F/22 & FCD IIB & 21 & CPS/SGS & I \\
$5 / \mathrm{M} / 18$ & FCD IIB & 14 & CPS & I \\
$6 / \mathrm{M} / 17$ & FCD IIB & 10 & CPS & I \\
$7 / F / 16$ & FCD IIB & 11 & CPS & I \\
$8 / \mathrm{M} / 29$ & FCD IIB & 21 & CPS & I \\
9/M/28 & FCD IIB & 21 & CPS & I \\
\hline
\end{tabular}

$F C D$ focal cortical dysplasia, $C P S$ complex partial seizures, $S G S$ secondary generalized seizures 
material represents good disease control tissue, since it is exposed to the same seizure activity, drugs, fixation time, and the age and gender are also the same.

\section{Tissue preparation}

Tissue was fixed in $10 \%$ buffered formalin and embedded in paraffin. Two representative paraffin blocks per case (containing the complete lesion or the largest part of the lesion resected at surgery) were sectioned, stained, and assessed. Paraffin-embedded tissue was sectioned at $6 \mu \mathrm{m}$, mounted on organosilane-coated slides (Sigma, St Louis, MO) and used for histological and immunocytochemical reactions as described below. Frozen tissue from control cortex and FCD tissue, stored at $-80^{\circ} \mathrm{C}$, was used for western blot analysis.

\section{Antibody characterization}

To document the presence of a heterogeneous population of cells, we used the following antibodies: glial fibrillary acidic protein (GFAP; polyclonal rabbit, DAKO, Glostrup, Denmark; 1:4,000; monoclonal mouse, DAKO; 1:50), vimentin (mouse clone V9, DAKO; 1:1,000), MAP2 (polyclonal rabbit; Chemicon; 1:500), neuronal nuclear protein (NeuN; mouse clone MAB377, Chemicon, Temecula, CA, USA; 1:2,000), non-phosphorylated neurofilament (SMI311; Sternberger monoclonals, Lutherville, MD; 1:1,000), human leukocyte antigen (HLA)-DP, -DQ, -DR (CR3/43; monoclonal mouse, DAKO; 1:400), CD68 (mouse clone PG-M1, DAKO; 1:200) and CD31 (mouse clone JC70A, DAKO; 1:100).

For the detection of VEGFA, VEGFB, and their receptors, the following antibodies (Abs) were used: VEGFA (G153-694, monoclonal mouse; recognizing VEGF 165 and 189 [51], Pharmingen, CA, USA; 1:100), VEGFA (A20, SC-152, polyclonal rabbit; raised against the N-terminus of VEGFA, recognizing VEGF 121, 165 and 189, Santa Cruz Bio., CA, USA; 1:100), VEGFB (H-70, SC13083, polyclonal rabbit; raised against amino acids 1-70 of human VEGFB, Santa Cruz Bio.; 1:20), Flt-1 (VEGFR1; C-17, SC-316, polyclonal rabbit, Santa Cruz Bio.; 1:100), Flk-1 (VEGFR-2; A-3, SC-6251, monoclonal mouse; Santa Cruz Bio.; 1:100). To allow comparative analysis, we used on frozen specimens of normal $(n=3)$ and FCD tissue $(n=2)$, two additional antibodies (which are not suitable for staining paraffin-embedded, formalinfixed tissue): VEGFR-1 (clone Flt-19, 1:400; developed against the recombinant human extracellular domain of VEGFR-1) and VEGFR-2 (clone KDR-1, 1:400; developed against the recombinant human extracellular domain of VEGFR-2), kindly provided by Dr. H. A. Weich (National Research Center for Biotechnology, Braunschweig, Germany), and previously characterized on human tissues [49, 64, 80]. Similar immunoreactivity patterns were observed on paraffin-embedded and frozen tissue.

The specificity of the antibodies used for immunocytochemistry on paraffin-embedded, formalin-fixed tissue (VEGFA, VEGFB, VEGFR-1, VEGFR-2; Santa Cruz Bio.), was further tested by performing western blot analysis of total homogenates of human control cortex. We also include one FCD case of which sufficient frozen material for blot analysis was available (Fig. 1). VEGFR1 and VEGFR-2 receptor proteins were detectable as a band of approximately 180 and $200 \mathrm{kDa}$, respectively; VEGFB was detectable as a band of approximately $40 \mathrm{kDa}$; VEGFA labeled a prominent band at approximately $48 \mathrm{kDa}$ and a

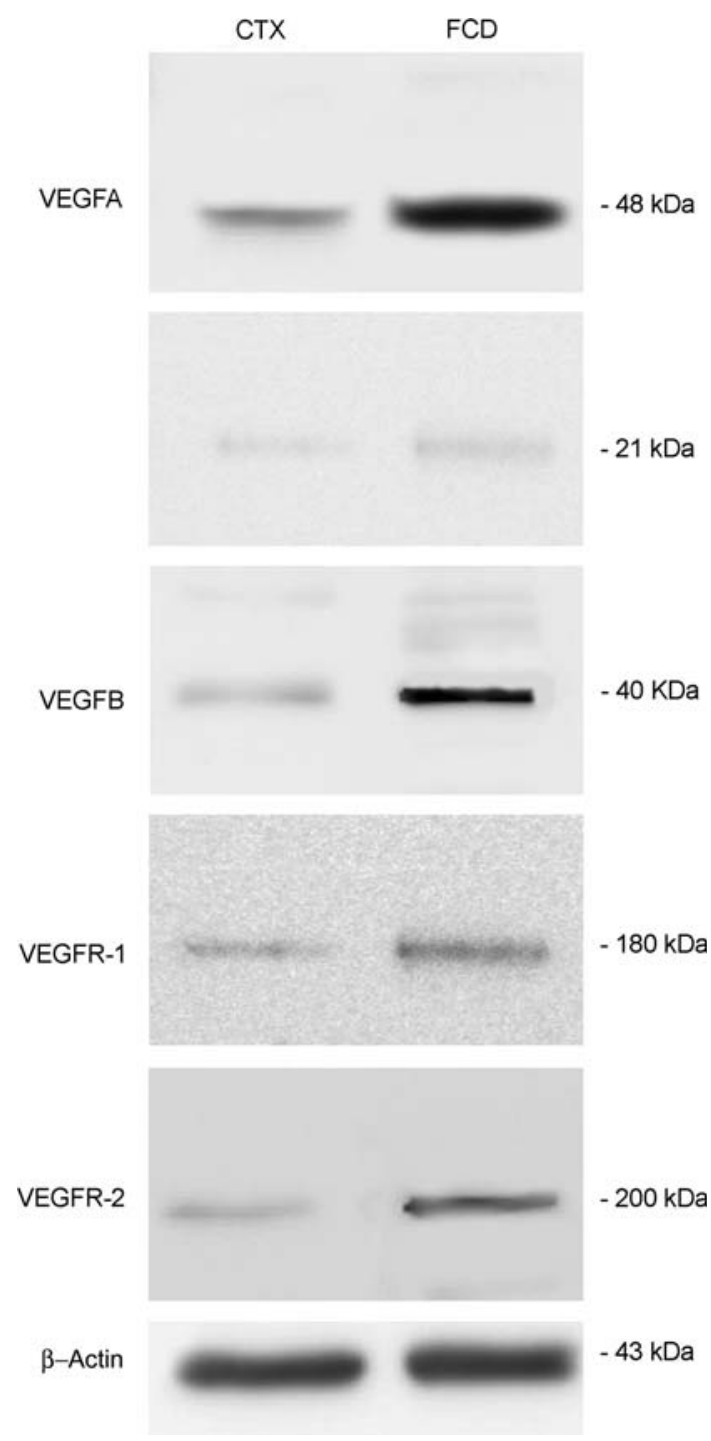

Fig. 1 Representative immunoblot of VEGFA, VEGFB, VEGFR-1, and VEGFR-2 in total homogenates from control cortex and FCD tissue. Expression of $\beta$-actin (as reference protein) is shown in the same protein extracts 
light band at $21 \mathrm{kDa}$ (reducing conditions), as recently reported in human brain tissue (control hippocampus and FCD; [56]). All immunoreactive bands disappeared after preadsorption with the corresponding peptide.

For immunoblot analysis, human normal cortex $(n=3)$ and FCD $(n=1)$ samples were homogenized in lysis buffer containing $10 \mathrm{mM}$ Tris (pH 8.0), $150 \mathrm{mM} \mathrm{NaCl}, 10 \%$ glycerol, $1 \% \mathrm{NP}-40$, Na-orthevanadate $(10.4 \mathrm{mg} / \mathrm{ml}), 5 \mathrm{mM}$ EDTA (pH 8.0), $5 \mathrm{mM} \mathrm{NaF}$, and protease inhibitor cocktail (Boehringer Mannheim, Germany). Protein content was determined using the bicinchoninic acid method [65]. Nonreducing conditions were used to improve the detection of the VEGFA antibody, as previously reported [8]. For electrophoresis, equal amounts of proteins $(30 \mu \mathrm{g} / \mathrm{lane})$ were separated by sodium dodecylsulfate-polyacrylamide gel electrophoretic (SDS-PAGE) analysis in 7.5-12.5\% gels. Separated proteins were transferred to nitrocellulose paper for $1 \mathrm{~h}$ and $30 \mathrm{~min}$, using a semi-dry electroblotting system (BioRad, Transblot SD, Hercules, CA, USA). Blots were incubated overnight in TTBS $(20 \mathrm{mM}$ Tris , $150 \mathrm{mM} \mathrm{NaCl}$, $0.1 \%$ Tween, $\mathrm{pH} 7.5) / 5 \%$ non-fat dry milk, containing the primary antibody (VEGFA, VEGFR-1, and VEGFR-2, 1:1,000; VEGFB, 1:200). After several washes in TTBS, the membranes were incubated in TTBS/5\% non-fat dry milk/1\% BSA, containing the goat anti-rabbit coupled to horseradish peroxidase (1:2,500; Dako, Denmark) for $1 \mathrm{~h}$. After washes in TTBS, immunoreactivity was visualized using an enhanced chemiluminescence kit (Amersham, Buckinghamshire, UK). Expression of $\beta$-actin (monoclonal mouse, Sigma, St Louis, MO; 1:50,000) was used as reference protein. Because of the limited availability of frozen material from FCD cases, a complete analysis with statistical comparison between control and FCD by immunoblot could not be performed.

\section{Immunocytochemistry}

Sections were deparaffinized, re-hydrated, and incubated for $20 \mathrm{~min}$ in $0.3 \% \mathrm{H}_{2} \mathrm{O}_{2}$ diluted in methanol to quench the endogenous peroxidase activity. Antigen retrieval was performed by incubation for $10 \mathrm{~min}$ at $121^{\circ} \mathrm{C}$ in citrate buffer (0.01 M, pH 6.0); sections were washed with phosphatebuffered saline (PBS), and incubated for $30 \mathrm{~min}$ in $10 \%$ normal goat serum (Harlan Sera-Lab, Loughborough, Leicestershire, UK). We incubated the sections with the primary antibodies overnight at $4^{\circ} \mathrm{C}$. Hereafter, sections were washed in PBS and we used the ready-for-use Powervision peroxidase system (Immunologic, Duiven, The Netherlands) and 3,3'-diaminobenzidine as chromogen to develop the staining. Sections were counterstained with hematoxylin, dehydrated, and coverslipped. Sections incubated without the primary antibody and excess of the antigenic peptide were essentially blank.
For double-labeling studies, after incubation overnight at $4^{\circ} \mathrm{C}$ with the primary antibodies, sections were incubated for $2 \mathrm{~h}$ at RT with Alexa Fluor ${ }^{\circledR}$ 568-conjugated anti-rabbit $\mathrm{IgG}$ and Alexa Fluor ${ }^{\circledR} 488$ anti-mouse $\operatorname{IgG}(1: 1,000$; Molecular Probes, The Netherlands). The VEGFR-2 antibody (monoclonal mouse) could only be combined with MAP2 and GFAP (polyclonal rabbit). Sections were analyzed by means of a laser scanning confocal microscope (Bio-Rad, Hercules, CA, USA; MRC1024) equipped with an argon-ion laser.

\section{Evaluation of immunostaining}

\section{Semi-quantitative evaluation of immunoreactivity}

As previously reported [3, 54], a semi-quantitative analysis was done using an Olympus microscope and examining in each section, high-power non overlapping fields (of $0.0655 \times 0.0655 \mathrm{~mm}$ width, each corresponding to $4.290 \mu \mathrm{m}^{2}$ ), defined in the center of the lesion using a square grid inserted into the eyepiece. A total microscopical area of $858.050 \mu \mathrm{m}^{2}$ was assessed per case. Neuronal cell bodies were differentiated from glia and glia-neuronal balloon cells on the basis of morphology. Balloon cells have eccentric nuclei and ballooned opalescent eosinophilic cytoplasm. The staining intensity was evaluated using a semi-quantitative three-point scale where immunoreactivity was defined as: - absent (0); + moderate (1); ++ strong staining (2); intensity score (Table 2). This score represents the predominant cell staining intensity found in each section for the different cell types (neurons, astrocytes, microglial cells, and balloon cells) as averaged from the selected fields (as previously described $[3,54]$ ).

\section{Frequency of cell staining}

In each slice, we assessed the number of neurons and astrocytes labeled by a specific $\mathrm{Ab}$ on the total number of each

Table 2 VEGFA, VEGFB, VEGFR-1, and VEGFR-2 distribution in different cellular types in cases of FCD (\% of cases with immunoreactive cells)

\begin{tabular}{|c|c|c|c|c|c|c|c|c|c|}
\hline & \multicolumn{9}{|c|}{ Focal cortical dysplasia $(n=9)$} \\
\hline & \multicolumn{3}{|c|}{ Neurons } & \multicolumn{3}{|c|}{ Astrocytes } & \multicolumn{3}{|c|}{ Balloon cells } \\
\hline & - & + & ++ & - & + & ++ & - & + & ++ \\
\hline VEGFA & 0 & $22 \%$ & $78 \%$ & 0 & $11 \%$ & $89 \%$ & 0 & $11 \%$ & $89 \%$ \\
\hline VEGFB & 0 & $33 \%$ & $67 \%$ & $78 \%$ & $22 \%$ & 0 & $78 \%$ & $22 \%$ & 0 \\
\hline VEGFR-1 & 0 & $55 \%$ & $45 \%$ & 0 & $22 \%$ & $78 \%$ & 0 & $33 \%$ & $67 \%$ \\
\hline VEGFR-2 & 0 & $11 \%$ & $89 \%$ & $55 \%$ & $45 \%$ & 0 & $22 \%$ & $45 \%$ & $33 \%$ \\
\hline
\end{tabular}


cell type within the lesion using an ocular grid [4]. This frequency score was assigned using three distinct categories: (1) $<10 \%$, rare; (2) $11-30 \%$, sparse; (3) $>30 \%$, high. The product of the intensity and the frequency scores was taken to give the total immunoreactivity score, as previously reported [23, 54].

For statistical analysis of data, SPSS for Windows was used. Data were compared using a non-parametric KruskalWallis test followed by a Mann-Whitney test to assess the difference between groups. $P<0.05$ was taken as the level of significance.

\section{Results}

Human material and histological features

All nine patients had chronic pharmacoresistant epilepsy and were all seizure-free postoperatively (Engel's class I; Table 1). The FCD cases included in this study have all the histopathological features of severe (type IIB) FCD, according to the classification of Palmini et al. [48]. The resected specimens consisted of disorganized neocortex containing immature neurons, giant neurons, dysmorphic neurons, and balloon cells. Neurons and balloon cells were also observed in the subcortical white matter and there was a prominent population of reactive astrocytes. Cells of the microglia/macrophage lineage were also observed within the dysplastic cortex, suggesting activation of inflammatory processes in FCD [6].

Expression of VEGF and VEGFR in normal temporal cortex and FCD

\section{Cellular distribution of VEGFA}

VEGFA staining was observed within the histologically normal cortex (Fig. 2a, b). The staining was strongest in pyramidal neurons, which displayed somatic staining and staining of the apical dendrites (Fig. 2b). Neuropil staining was weak and resting glial cells did not show VEGFA immunoreactivity (IR). Weak staining was observed in endothelial cells. Autopsy material and the perilesional cortex showed similar IR.

In the majority of FCD cases, strong VEGFA immunoreactivity (IR) was observed in dysplastic neurons located throughout the dysplastic cortex (Fig. 2c-e; Table 2; Fig. 6). Strong staining was also detected in balloon cells, reactive astrocytes, and in perivascular astrocytic end-feet (Fig. 2f-i; Table 2; Fig. 6). Endothelial IR was weak. Double-labeling experiments confirmed expression in reactive astrocytes, neurons, and in CD68+ macrophages (Fig. 2p). Immunocytochemistry using two different antibodies to
VEGF (Pharmingen and Santa Cruz Bio.) demonstrated similar patterns.

\section{Cellular distribution of VEGFB}

Histologically normal cortex displayed only weak VEGFB IR (Fig. 3a). Both autopsy and surgical specimens showed light staining in pyramidal neurons and in endothelial cells. Glial cells did not show VEGFB IR.

In FCD specimens, moderate to strong VEGFB IR was observed within the dysplastic cortex (Fig. 3b; Table 2; Fig. 6) with strong VEGFB IR in dysplastic neurons (Fig. 3c). In the majority of cases (seven out of nine), balloon cells and reactive astrocytes did not express VEGFB (Fig. 3d; Table 2; Fig. 6). Double-labeling experiments confirmed the absence of VEGFB IR in GFAP-positive cells (astrocytes), whereas co-localization was found with neurofilament in dysplastic neurons (Fig. 3h-j). VEGFB IR was also observed in CD68+ macrophages (Fig. 3k).

\section{Cellular distribution of VEGFR-1}

Histologically normal cortex (autopsy and surgical specimens) displayed only weak VEGFR-1 IR, which was restricted to pyramidal neurons (Fig. 4a). IR in blood vessels was weak (Fig. 4b). Glial cells did not show VEGFR-1 IR.

In FCD specimens, moderate to strong VEGFR-1 staining was observed within the dysplastic cortex (Fig. 4c-g; Table 2; Fig. 6). VEGFR-1 IR was observed in different cell types, including dysplastic neurons, astrocytes, and endothelial cells. Double-labeling experiments confirmed the co-localization of VEGFR-1 IR with neuronal (inset in Fig. 4c), endothelial (inset in Fig. 4d), and glial (Fig. 4h-j) markers. Additionally, expression of VEGFR-1 was observed in CD68+ macrophages (Fig. 4k-m).

\section{Cellular distribution of VEGFR-2}

VEGFR-2 staining was observed within the histologically normal cortex (autopsy and perilesional zone) in pyramidal neurons (Fig. 5a). IR in blood vessels was weak (Fig. 5b). Glial cells did not show VEGFB IR.

In the large majority of FCD cases (eight out of nine), VEGFR-2 was strongly expressed in dysplastic neurons (Fig. 5c, e; Table 2; Fig. 6). VEGFR-2 IR was also detected in balloon cells, but only three out of nine cases displayed strong staining for VEGFR-2 (Fig. 5f; Table 2). Endothelial expression was weak. In many FCD cases (five out of nine), expression of VEGFR-2 was undetectable in reactive astrocytes (Table 2). Double-labeling experiments confirmed the co-localization of VEGFR-2 IR with neuronal markers 


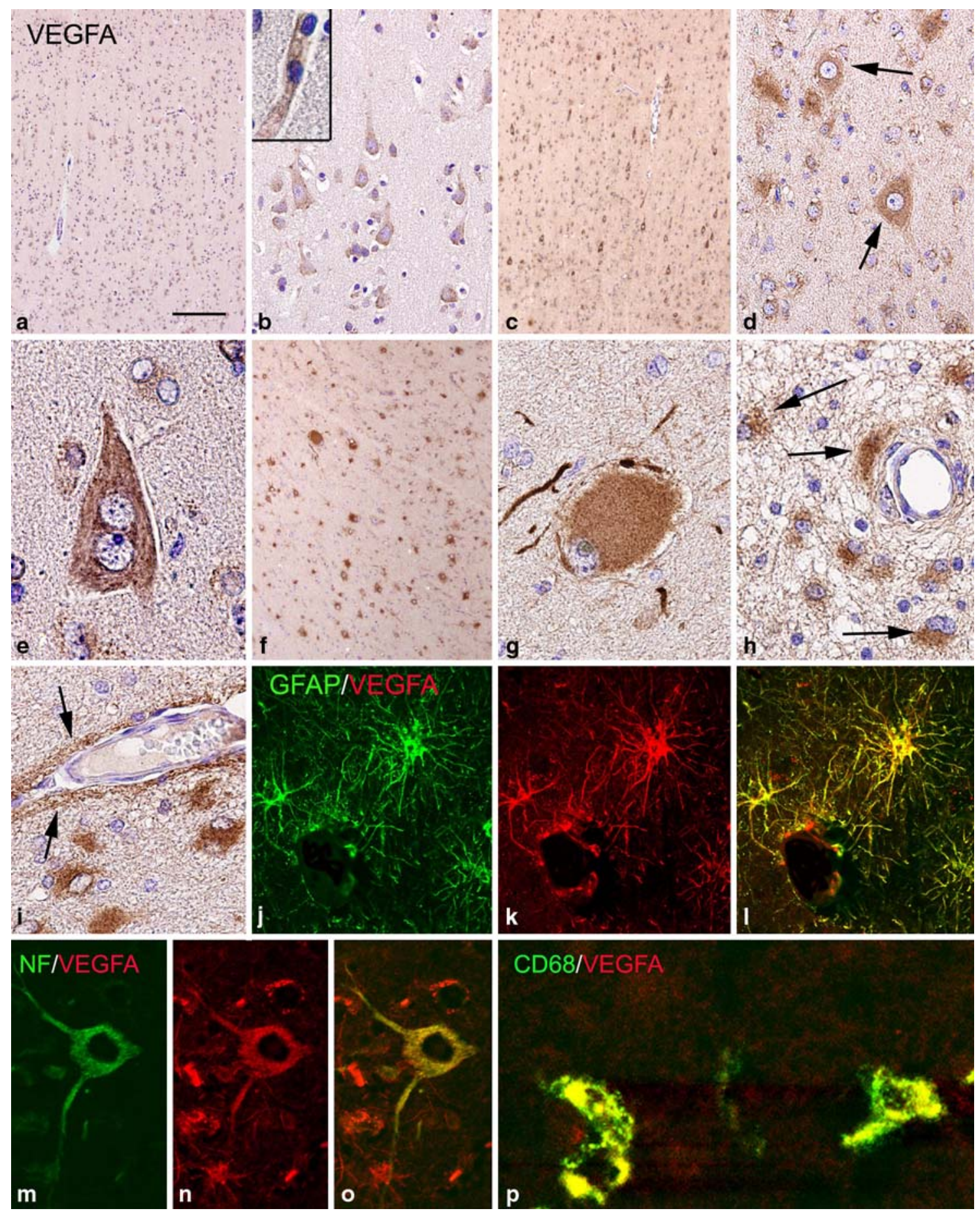

Fig. 2 VEGFA immunoreactivity in focal cortical dysplasia type IIB. a VEGFA immunoreactivity (IR) within the histologically normal adult cortex. b High magnification showing somatic staining in pyramidal neurons (inset: vascular staining). c VEGFA in focal cortical dysplasia (FCD; type IIB) showing strong IR within the dysplastic cortex. d High magnification showing VEGFA IR in dysplastic neurons (arrows). e A binucleated VEGFA positive dysplastic neuron. $f$ VEGFA IR within the subcortical dysplastic region. $g$ VEGFA expression in a balloon cell. $\mathbf{h}, \mathbf{i}$ VEGFA expression in reactive astrocytes (arrows

in $\mathbf{i}$ indicate perivascular astrocytic end-feet) $\mathbf{j}-\mathbf{l}$ double-labeling of GFAP (green, $\mathbf{j}$ ) with VEGFA ( $r e d, \mathbf{k}$ ) shows co-localization (yellow, l) in astrocytes. $\mathbf{m}-\mathbf{o}$ Double-labeling of non-phosphorylated neurofilament (SMI311; NF, green, m) with VEGFA (red, n) shows co-localization (yellow, o) in dysplastic neurons. p Merged image showing co-localization of CD68 (green) with VEGFA (red) in macrophages. Scale bar in a a, c, f $400 \mu \mathrm{m}$; b, d $120 \mu \mathrm{m}$; e, g-i $35 \mu \mathrm{m}$; j-o $40 \mu \mathrm{m}$; p $18 \mu \mathrm{m}$ 
Fig. 3 VEGFB immunoreactivity in focal cortical dysplasia type IIB. a Histologically normal adult cortex, showing neuronal distribution of VEGFB with weak immunoreactivity (IR) in pyramidal cell neurons (high magnification of a pyramidal neuron is shown in the inset al); weak staining was also observed in blood vessels (inset aII). b VEGFB in focal cortical dysplasia (FCD; type IIB) showing strong IR within the dysplastic cortex. c Strong VEGFB IR in dysplastic neurons of different size and shape (arrows). d Undetectable VEGFB IR in balloon cells (arrows). e-g Absence of co-localization between GFAP (green, e) with VEGFB $(\mathrm{red}, \mathbf{f})$ in astrocytes $(\mathbf{g}$, merged image). $\mathbf{h}-\mathbf{j}$ Double-labeling of non-phosphorylated neurofilament (SMI311; NF, green, $\mathbf{h})$ with VEGFB (red, i) shows colocalization (yellow, $\mathbf{j}$ ) in dysplastic neurons. k Merged image showing co-localization of CD68 (CD68; green) with VEGFB (red) in macrophages. Scale bar in a a, b $200 \mu \mathrm{m}$; c-j $40 \mu \mathrm{m}$; $\mathrm{k} 18 \mu \mathrm{m}$
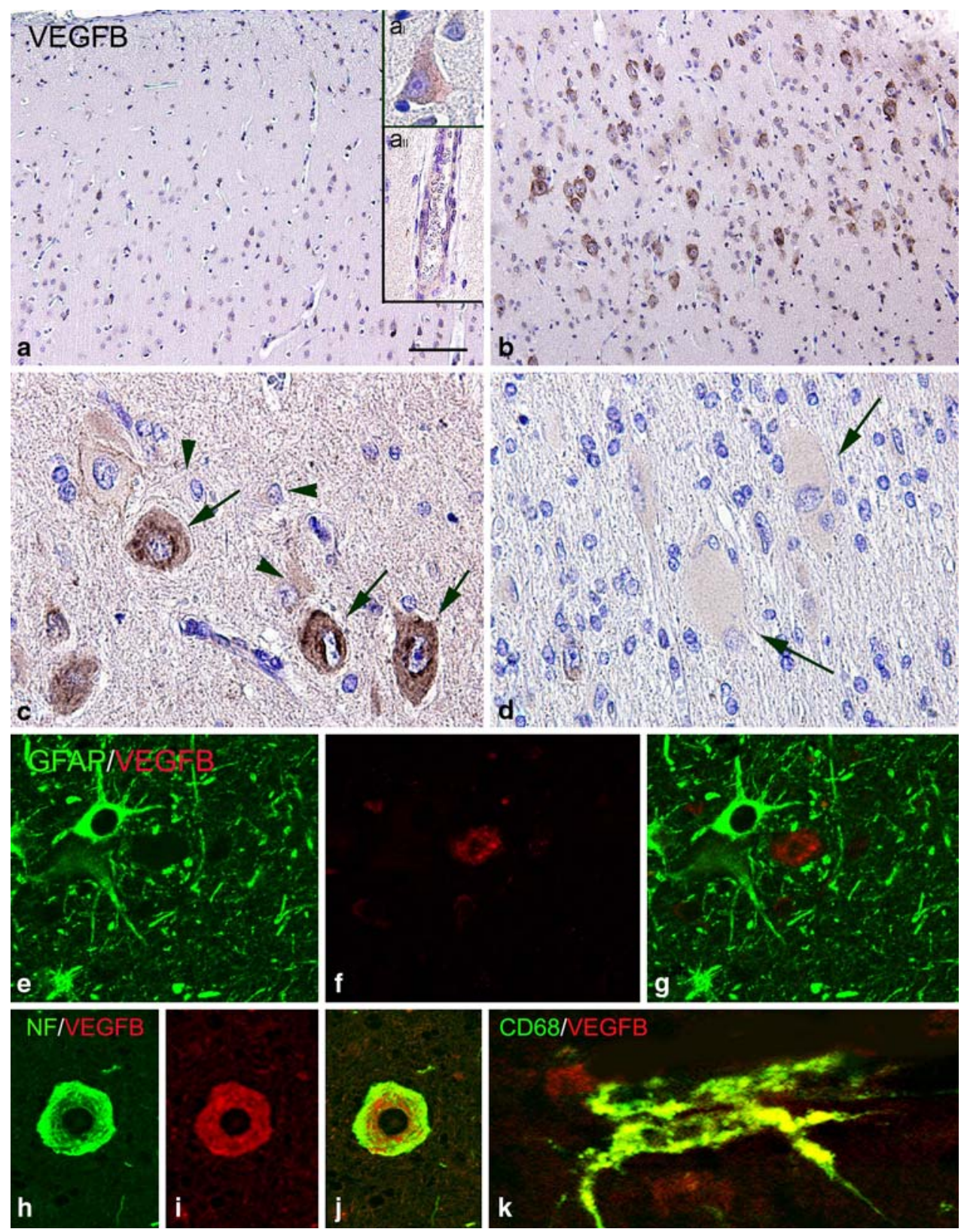

(neurofilament or MAP2, Fig. 5e, g-i) within the dysplastic cortex.

\section{Discussion}

In addition to their role in angiogenesis, VEGF proteins and their receptors have been implicated in several neurological disorders, including epilepsy $[13,44,56]$. In the present study, we demonstrate a prominent expression of VEGFA, VEGFB, and their signaling receptors in FCD type IIB, a malformation of cortical development associated with intractable epilepsy. This is particularly interesting in view of the recently proposed role of VEGFs and their signaling pathways during development and in epilepsy-associated pathologies [13, 26, 33, 69, 76].

Expression of VEGFA and VEGFB in normal temporal cortex

In histologically normal temporal cortex (autopsy and perilesional zone), we have shown weak expression of both VEGFA and VEGFB in cortical neurons. Expression of VEGFA and VEGFB, including both mRNA and protein, has been demonstrated in neurons in adult rodent brain [39, 41, 42, 72]. In human adult brain, only few studies have described neuronal expression of VEGFA in control tissue $[8,78]$, which was similar to 
Fig. 4 VEGFR-1 immunoreactivity in focal cortical dysplasia type IIB. a, b Histologically normal adult cortex (a) and white matter (b) showing weak immunoreactivity (IR) in neurons (a) and blood vessels (b; arrowheads). c, $\mathbf{d}$ VEGFR-1 in focal cortical dysplasia (FCD; type IIB) showing strong IR in dysplastic neurons (c; arrows) and in blood vessels (d; arrows). Inset in c Co-localization between non-phosphorylated neurofilament (SMI311; NF, green) with VEGFR-1 (red) in dysplastic neurons. Inset in d Co-localization between CD31 (endothelial marker; green) with VEGFR-1 (red) in blood vessels. e-g Strong IR in balloon cells of different size (arrows) and glial cells (arrowheads in $\mathbf{e}$ ). $\mathbf{h}-\mathbf{j}$ Colocalization between GFAP (green, h) with VEGFR-1 (red, i) in astrocytes ( $\mathbf{j}$, merged image). $\mathbf{k}-\mathbf{m}$ Co-localization of CD68 (CD68; green, $\mathbf{k}$ ) with VEGFR-1 ( $r e d, \mathbf{l})$ in macrophages (m, merged image). Scale bar in a a-d and $\mathrm{h}-\mathrm{m}$ $40 \mu \mathrm{m}$; e-g $35 \mu \mathrm{m}$

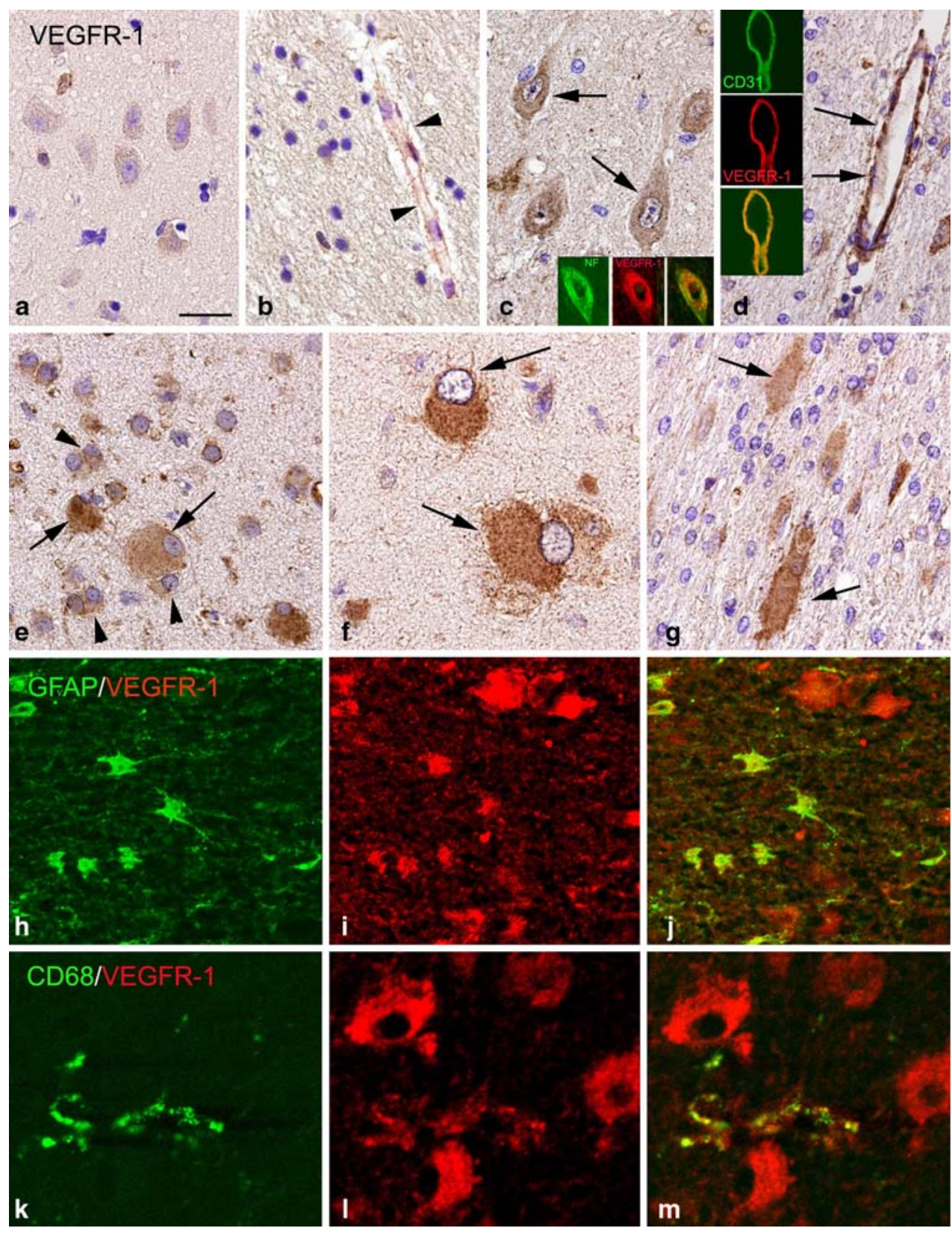

our observed staining pattern in the control temporal specimens.

To our knowledge, previous studies of VEGFB protein expression in human control cortex have not been described. However, VEGFB mRNA was detected in human hippocampal cortex [24], and VEGFB mRNA and protein expression has been described in adult rodent brain $[36,42]$. In control rat brain, VEGFB was constitutively expressed in endothelial cells [42]. In our study, we observed only weak endothelial VEGFB IR in blood vessels. In agreement with previous studies [8, 36, 78], immunoreactivity (IR) for both VEGFs was not observed in glial cells within control specimens.
Differential cellular distribution of VEGFA and VEGFB in FCD

In the present study, we provide evidence for a consistent expression of both VEGFA and VEGFB within the dysplastic cortex of patients with FCD. Both VEGFs are highly expressed in dysplastic neurons; however, only the VEGFA protein is prominently expressed in reactive astrocytes. Expression of VEGFA in astrocytes has been shown in several other pathologies associated with reactive gliosis, such as ischemic stroke, traumatic brain injury, neurodegenerative disorders, and the hippocampus following entorhinal deafferentation $[8,27,59,78,79]$. In addition, we previously 
Fig. 5 VEGFR-2 immunoreactivity in focal cortical dysplasia type IIB. a, b Histologically normal adult cortex (a) and white matter (b) showing moderate immunoreactivity (IR) in pyramidal cells (a); in the white matter, endothelial IR was weak and glial IR was under detection level (b). c, d VEGFR-2 in focal cortical dysplasia (FCD; type IIB) showing strong IR in dysplastic neurons (arrows in c), but weak IR in blood vessels

(arrowheads in d). e, f Strong IR in a dysplastic neuron (arrow in e) and in a balloon cell (arrow in f), but weak IR in glial cells (arrowheads in $\mathbf{e}, \mathbf{f}$ ). Inset in $\mathbf{e}$ Co-localization between nonphosphorylated neurofilament (SMI311; NF, green) with VEGFR-2 (red) in a dysplastic neuron. $\mathbf{g}-\mathbf{i}$ Co-localization between MAP-2 (green, g) with VEGFR2 (red, $\mathbf{h})$ in balloon cells (i, merged image). Scale bar in a a-d and g-i $40 \mu \mathrm{m}$; e, f $35 \mu \mathrm{m}$

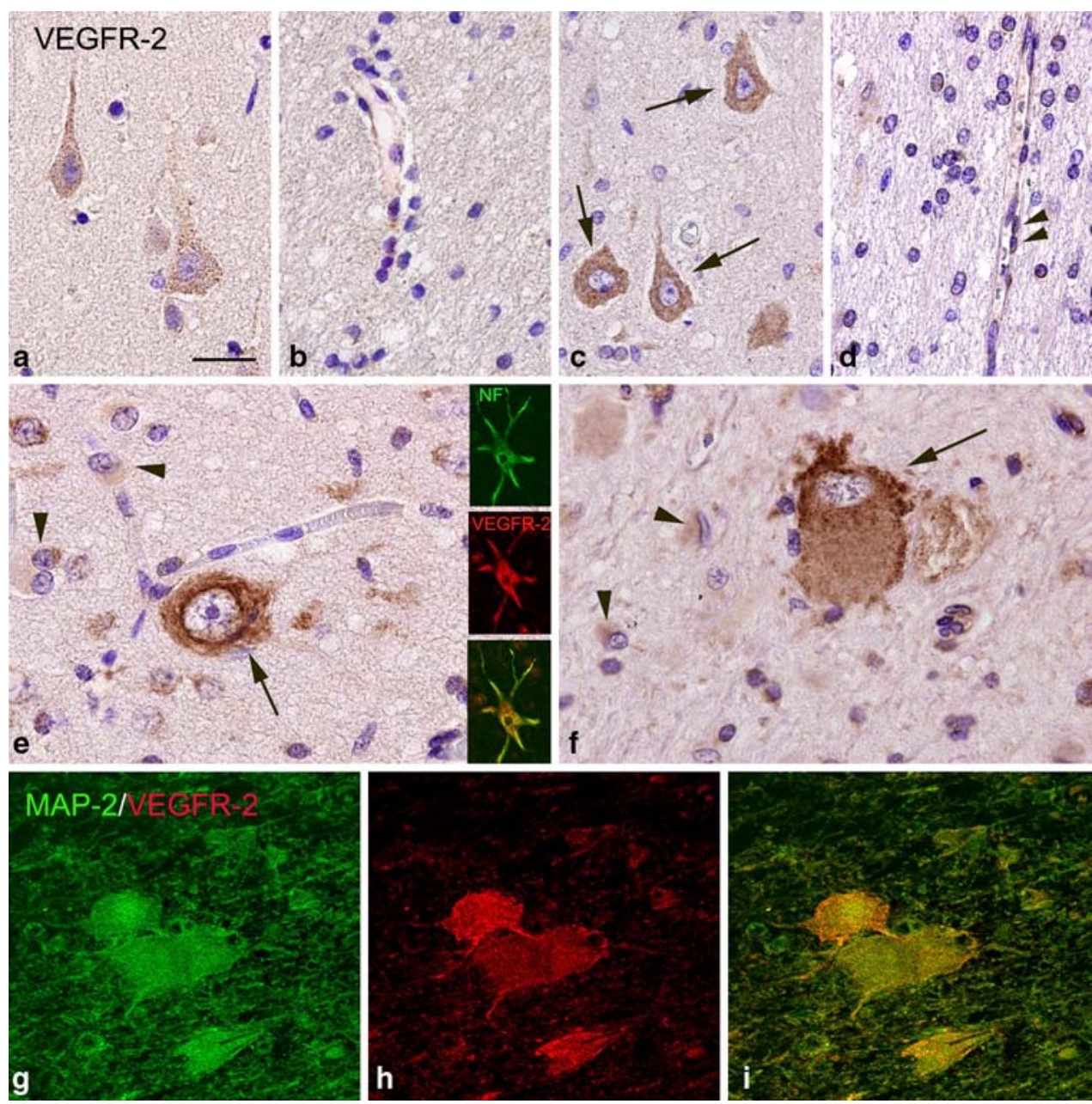

reported upregulation of both neuronal and glial VEGFA expression in patients with hemimegalenchephaly, an epilepsy-associated malformation of cortical development [5, 7]. In the present study, we also observed expression of VEGFA in balloon cells, which are characteristic cell types of severe FCD [48]. Whether these cells are glial or neuronal in nature is still controversial [12].

Induction of both neuronal and astroglial VEGFA expression has been shown in different experimental models of seizures and human temporal lobe epilepsy (TLE) [13, 44, 56]. Rigau et al. [56] showed increased levels of VEGFA in the hippocampus of several cases of TLE, including two cases of focal dysplasia. All TLE cases showed VEGFA expression in pyramidal neurons and granule cells of the hippocampus [56]. However, immunocytochemical analysis of the temporal cortex and the FCD cases was not performed.

The molecular mechanism underlying the induction of VEGFA expression after seizures remains unclear. One possible mechanism, which has been proposed to explain the association between seizure activity and the induction of VEGFA expression, is represented by the stabilization of the hypoxia inducible factor- $1 \alpha$ (HIF- $1 \alpha)$. HIF- $1 \alpha$ is a tran- scription factor which upregulates VEGFA transcription under hypoxic conditions [21, 38, 61]. Hypoxia may occur during seizures, representing an important trigger in the induction of VEGFA expression, particularly in case of long lasting seizures, such as in status epilepticus models. However, VEGFA expression is already induced after acute seizures [44] and the mechanisms that regulate VEGFA expression are complex. Several transcription factors, including AP- $1, \mathrm{HIF}-1 \alpha$, and NF- $\kappa \mathrm{B}$, have been identified to regulate VEGFA expression [31], and recently it has also been shown that inflammatory cytokines, such as interleukin- $1 \beta$ (IL- $1 \beta$ ), activate $H I F 1 \alpha$ and VEGFA gene expression in primary human astrocytes [2]. Interestingly, increased expression of proinflammatory cytokines and related molecules has been reported in both animal models and human epilepsy-associated pathologies, including FCD $[3,15,54,77]$. In addition, VEGFA has been demonstrated to be a key mediator of the inflammatory process $[14,35]$. Thus, we might speculate that the prominent expression of VEGFA within the dysplastic cortex could be a critical component of the complex cascade of events leading to a chronic inflammatory state and the sustained seizure activity 
Fig. 6 Distribution of immunoreactivity scores (total score; see details in "Materials and methods" section) in neurons and astrocytes of control, perilesional, and FCD specimens. a, e VEGFA; $\mathbf{b}, \mathbf{f}$ VEGFB; $\mathbf{c}, \mathbf{g}$ VEGFR-1; d, h VEGFR-2. a-d Neurons; $\mathbf{e}-\mathbf{h}$ astrocytes. IR scores of VEGFs and VEGFRs in neurons of FCD were greater than IR scores of VEGFs and VEGFRs of control and perilesional cortex; scores of VEGFA and VEGFRs in astrocytes of FCD were greater than IR scores of VEGFA and VEGFRs of control and perilesional cortex $(P<0.05)$. There were no significant differences in IR scores of VEGFs and VEGFRs between control and perilesional cortex
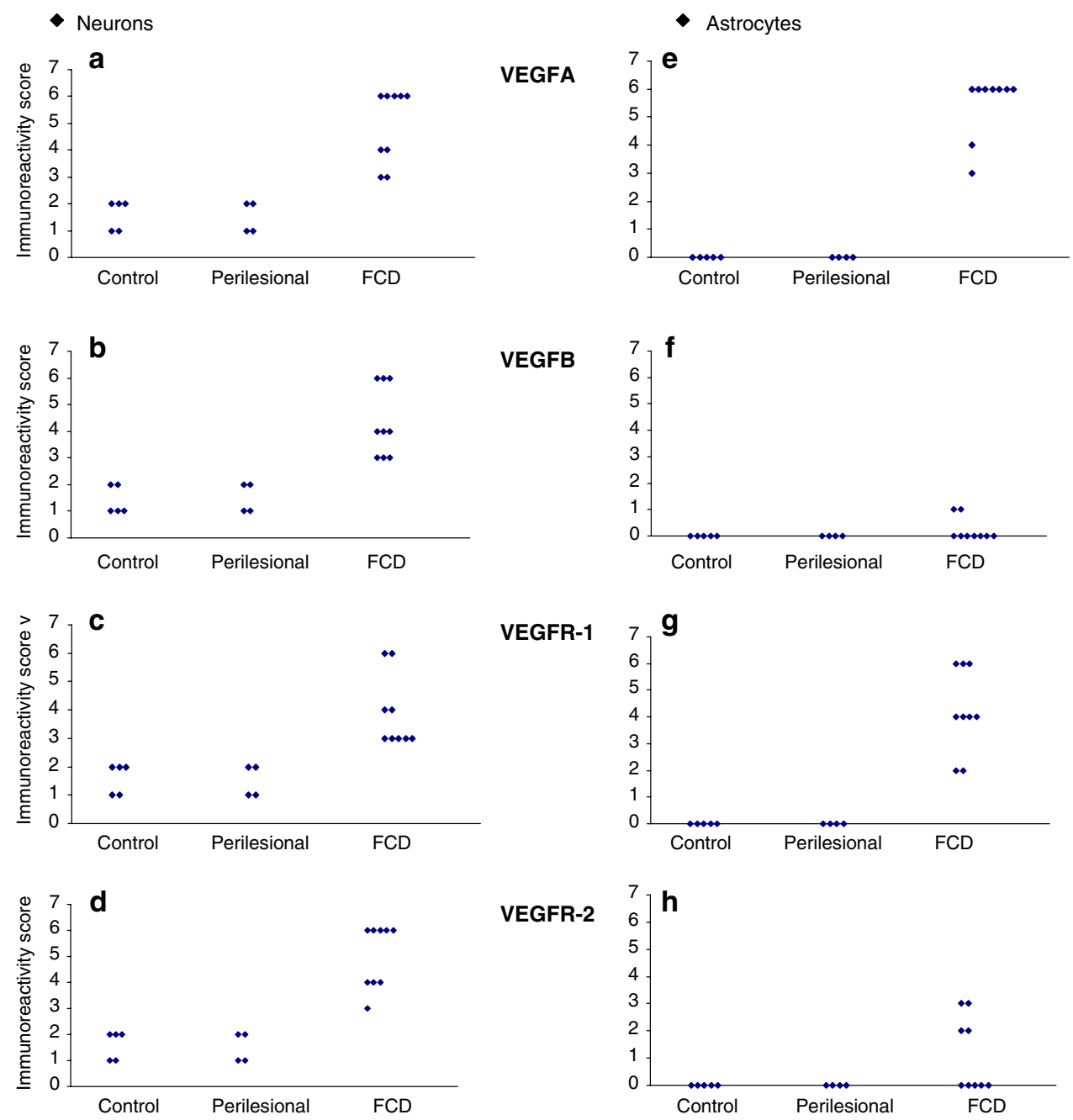

$[76,77]$. With respect to inflammation, inflammatory cells, such as macrophages, can also release various angiogenic cytokines including VEGFs [71]. Accordingly, we observed expression of both VEGFA and VEGFB in macrophages (CD68-positive cells), as previously shown in animal models of brain ischemia [11, 42, 52].

VEGFA effects can also compromise the integrity of the blood-brain barrier (BBB; [60]). Interestingly, alterations of the BBB permeability have been recently observed in both human and experimental temporal lobe epilepsy with positive correlation between the increased vascular permeability and the occurrence of spontaneous seizures in chronic epileptic rats $[55,56,75]$.

In contrast, several studies highlight a dichotomous function of VEGFA, also demonstrating a neuroprotective role [13, 47]. Administration of VEGFA and neuronal expression of VEGFA have been shown to stimulate neurogenesis in vitro and in vivo [9, 28]. In addition, it has been suggested that the neuroprotective effects of VEGFA are mediated by the neuronal VEGFR-2 and the subsequent activation of the PI3K/Akt survival pathway [32, 67].
VEGFB expression is not induced by hypoxia or several transcription factors known to regulate VEGFA expression [18], as the promoter region of VEGFB lacks HIF-1 and AP1 sites [43, 62]. The regulation of the expression of VEGFB remains unknown. Since all cases examined were associated with epilepsy, we cannot exclude that chronic seizure activity could also contribute to the VEGFB expression in FCD specimens. Alternatively, since VEGFB expression has been shown to be prominent during early brain development [36], the strong neuronal expression of VEGFB could represent an intrinsic and immature feature of the dysplastic neuronal cells that could contribute to their survival. Recent studies using VEGFB knock-out mice demonstrate a neurotrophic and neuroprotective activity of VEGFB, exerting a direct action on neurons, and promoting neurogenesis [68, 69].

This is an observational study and we were, therefore, not able to investigate the spatio-temporal regulation of the VEGF system. Further research in animal models of cortical dysplasia is clearly needed to elucidate the role of VEGFs and their signaling pathways in the histogenesis or epileptogenesis of developmental disorders. 
Expression of VEGF receptors in normal temporal cortex

In histologically normal temporal cortex (autopsy and perilesional zone), VEGFR-1 and VEGFR-2 showed a similar pattern of expression, with weak to moderate immunostaining in pyramidal neurons. Neuronal expression of VEGFRs' mRNA and protein has been reported in adult human and rodent brain, with strong expression in the hippocampus $[8,11,78,79]$. In agreement with these studies, we did not detect glial VEGFR expression in histologically normal cortex and only weak VEGFR expression was observed in endothelial cells.

Differential cellular distribution of VEGFR-1 and VEGFR-2 in FCD

Consistent expression of both VEGFR-1 and VEGFR-2 was detected within the dysplastic cortex of patients with FCD. Both receptors were upregulated in dysplastic neurons. Increased expression of the VEGFRs and, in particular VEGFR-1, was observed in reactive astrocytes. Upregulation of VEGFRs in neurons and reactive astrocytes has been shown in several other pathological conditions including ischemia, neurodegenerative diseases, and trauma [8, 11, 37, 39, 66, 79]. Recently, increased expression of VEGFR-2 has been shown in several cases of TLE, including two cases of cortical dysplasia [56]. Immunocytochemical analysis demonstrated expression only in endothelial cells, whereas neuronal VEGFR-2 IR was not detected in either control hippocampus or TLE specimens [56]. Differences in the phenotypes of cells expressing VEGFRs have been observed in several other studies $[8,30,52]$. These discrepancies may be caused by differences in experimental methods, tissue processing, or the use of different antibodies that recognize different epitopes.

Our results support the neuronal expression of VEGFR-2 recently reported in human brain [8]. The similar expression pattern of VEGFA and VEGFR-2, with prominent neuronal IR, suggests autocrine/paracrine effects on dysplastic neurons, supporting the hypothesis of a mechanism to protect abnormal neurons from cell death associated with seizures. Autocrine and/or paracrine effects of VEGFA are supported by the observation that administration of VEGFA has been shown to induce mRNA and protein expression of both receptors in adult rat brain [34, 57]. A protective mechanism of VEGFA has been suggested in epileptic rats, showing that VEGFA may reduce spontaneous discharges in epileptic rats [40]. Therefore, upregulation of VEGFA could represent an endogenous compensatory mechanism to reduce excitability and to prevent cell loss after severe seizures. Accordingly, infusion of
VEGFA into the hippocampus has been shown to protect against neuronal cell loss after pilocarpine-induced status epilepticus [45].

In the present study, we also provide evidence for the expression of VEGFR-1 in activated cells of the microglia/ macrophage lineage, which have been shown to be present in FCD specimens [6]. This is in agreement with previous in vitro and in vivo studies [11, 20] showing VEGFR-1 expression in activated microglial cells. These observations suggest that the microglia/macrophage lineage is also a target for VEGF, which may affect chemotaxis and proliferation of these cells, contributing to the inflammatory state in the epileptic brain.

There is substantial information about the function and the signaling through VEGFR-2; in contrast, signaling through VEGFR-1 remains poorly understood and has been a matter of discussion. A decoy role has been proposed for VEGFR-1, but more recently, functional signaling via VEGFR-1 has been reported (for reviews see [43, 67]). These observations may give rise to new therapeutic strategies focusing on VEGFR-1 specific ligands, such as VEGFB [43].

Although a rapid induction of VEGF and its receptors has been shown in different experimental models of seizures [13, 44, 56], seizures alone cannot account for changes in neuronal and glial expression in FCD since perilesional tissue was exposed to seizures but did not show significant upregulation of VEGFs and/or VEGFRs. Therefore, the lesion per se or the concomitant presence of the lesion and the epileptic activity, are likely to play a role in modulating the VEGF system in these developmental disorders.

\section{Conclusions}

Our observed cellular distribution of VEGFA, VEGFB, and their signaling receptors indicate that different cellular components of FCD are involved in VEGF-signaling. In this context, future studies, using both in vivo and in vitro models, will be important to achieve a better understanding of the role of the VEGF-mediated pathways in the histogenesis and epileptogenesis of developmental lesions associated with intractable chronic epilepsy. Presently, signaling via VEGF receptors is not targeted by existing therapies in epileptic patients, but it can be potentially useful in view of its involvement in the regulation of neurogenesis, inflammation, and BBB integrity. However, an effective therapeutic intervention based on modulation of the VEGF system has to take into consideration the specific role of VEGFA and VEGFB and the multiple effects (protective and/or detrimental) reported for VEGFA. 
Acknowledgments This work was supported by the National Epilepsy Fund (NEF 05-11; E. Aronica and K. Boer) and by EU-FP7project (202167; E. Aronica).

Open Access This article is distributed under the terms of the Creative Commons Attribution Noncommercial License which permits any noncommercial use, distribution, and reproduction in any medium, provided the original author(s) and source are credited.

\section{References}

1. Aase K, Lymboussaki A, Kaipainen A, Olofsson B, Alitalo K, Eriksson U (1999) Localization of VEGF-B in the mouse embryo suggests a paracrine role of the growth factor in the developing vasculature. Dev Dyn 215:12-25

2. Argaw AT, Zhang Y, Snyder BJ, Zhao ML, Kopp N, Lee SC, Raine CS, Brosnan CF, John GR (2006) IL-1beta regulates bloodbrain barrier permeability via reactivation of the hypoxia-angiogenesis program. J Immunol 177:5574-5584

3. Aronica E, Boer K, van Vliet EA, Baayen JC, Redeker S, Spliet WGM, Lopes da Silva FH, Wadman WJ, Troost D, Gorter JA (2007) Complement activation in experimental and human temporal lobe epilepsy. Neurobiol Dis 26:497-511

4. Aronica E, Gorter JA, Jansen GH, van Veelen CW, van Rijen PC, Ramkema M, Troost D (2003) Expression and cell distribution of group I and group II metabotropic glutamate receptor subtypes in taylor-type focal cortical dysplasia. Epilepsia 44:785-795

5. Baybis M, Lynch D, Lee A, Patel A, McKhann G 2nd, Chugani D, Kupsky WJ, Aronica E, Crino PB (2004) Altered expression of neurotransmitter-receptor subunit and uptake site mRNAs in hemimegalencephaly. Epilepsia 45:1517-1524

6. Boer K, Spliet WG, van Rijen PC, Redeker S, Troost D, Aronica E (2006) Evidence of activated microglia in focal cortical dysplasia. J Neuroimmunol 173:188-195

7. Boer K, Troost D, Spliet WG, van Rijen PC, Redeker S, Crino PB, Aronica E (2007) A neuropathological study of two autopsy cases of syndromic hemimegalencephaly. Neuropathol Appl Neurobiol 33:455-470

8. Brockington A, Wharton SB, Fernando M, Gelsthorpe CH, Baxter L, Ince PG, Lewis CE, Shaw PJ (2006) Expression of vascular endothelial growth factor and its receptors in the central nervous system in amyotrophic lateral sclerosis. J Neuropathol Exp Neurol 65:26-36

9. Cao L, Jiao X, Zuzga DS, Liu Y, Fong DM, Young D, During MJ (2004) VEGF links hippocampal activity with neurogenesis, learning and memory. Nat Genet 36:827-835

10. Carmeliet P, Storkebaum E (2002) Vascular and neuronal effects of VEGF in the nervous system: implications for neurological disorders. Semin Cell Dev Biol 13:39-53

11. Choi JS, Kim HY, Cha JH, Choi JY, Chun MH, Lee MY (2007) Upregulation of vascular endothelial growth factor receptors Flt-1 and Flk-1 in rat hippocampus after transient forebrain ischemia. J Neurotrauma 24:521-531

12. Crino PB, Miyata H, Vinters HV (2002) Neurodevelopmental disorders as a cause of seizures: neuropathologic, genetic, and mechanistic considerations. Brain Pathol 12:212-233

13. Croll SD, Goodman JH, Scharfman HE (2004) Vascular endothelial growth factor (VEGF) in seizures: a double-edged sword. Adv Exp Med Biol 548:57-68

14. Croll SD, Ransohoff RM, Cai N, Zhang Q, Martin FJ, Wei T, Kasselman LJ, Kintner J, Murphy AJ, Yancopoulos GD, Wiegand SJ (2004) VEGF-mediated inflammation precedes angiogenesis in adult brain. Exp Neurol 187:388-402

15. De Simoni MG, Perego C, Ravizza T, Moneta D, Conti M, Marchesi F, De Luigi A, Garattini S, Vezzani A (2000) Inflammatory cytokines and related genes are induced in the rat hippocampus by limbic status epilepticus. Eur J Neurosci 12:2623-2633

16. Dvorak HF (2005) Angiogenesis: update 2005. J Thromb Haemost 3:1835-1842

17. Engel JJ (1993) Outcome with respect to epileptic seizures. In: Engel JJ (ed) Surgical treatment of the epilepsies. Raven Press, New York, pp 609-621

18. Enholm B, Paavonen K, Ristimaki A, Kumar V, Gunji Y, Klefstrom J, Kivinen L, Laiho M, Olofsson B, Joukov V, Eriksson U, Alitalo K (1997) Comparison of VEGF, VEGF-B, VEGF-C and Ang-1 mRNA regulation by serum, growth factors, oncoproteins and hypoxia. Oncogene 14:2475-2483

19. Ferrara N, Gerber HP (2001) The role of vascular endothelial growth factor in angiogenesis. Acta Haematol 106:148-156

20. Forstreuter F, Lucius R, Mentlein R (2002) Vascular endothelial growth factor induces chemotaxis and proliferation of microglial cells. J Neuroimmunol 132:93-98

21. Forsythe JA, Jiang BH, Iyer NV, Agani F, Leung SW, Koos RD, Semenza GL (1996) Activation of vascular endothelial growth factor gene transcription by hypoxia-inducible factor 1 . Mol Cell Biol 16:4604-4613

22. Galvan V, Greenberg DA, Jin K (2006) The role of vascular endothelial growth factor in neurogenesis in adult brain. Mini Rev Med Chem 6:667-669

23. Geurts JJ, Wolswijk G, Bo L, vander Valk P, Polman CH, Troost D, Aronica E (2003) Altered expression patterns of group I and II metabotropic glutamate receptors in multiple sclerosis. Brain 126:1755-1766

24. Gollmer JC, Ladoux A, Gioanni J, Paquis P, Dubreuil A, Chatel M, Frelin C (2000) Expression of vascular endothelial growth factor-b in human astrocytoma. Neuro Oncol 2:80-86

25. Greenberg DA, Jin K (2005) From angiogenesis to neuropathology. Nature 438:954-959

26. Hashimoto T, Zhang XM, Chen BY, Yang XJ (2006) VEGF activates divergent intracellular signaling components to regulate retinal progenitor cell proliferation and neuronal differentiation. Development 133:2201-2210

27. Issa R, Krupinski J, Bujny T, Kumar S, Kaluza J, Kumar P (1999) Vascular endothelial growth factor and its receptor, KDR, in human brain tissue after ischemic stroke. Lab Invest 79:417-425

28. Jin K, Zhu Y, Sun Y, Mao XO, Xie L, Greenberg DA (2002) Vascular endothelial growth factor (VEGF) stimulates neurogenesis in vitro and in vivo. Proc Natl Acad Sci USA 99:11946-11950

29. Jin KL, Mao XO, Greenberg DA (2000) Vascular endothelial growth factor: direct neuroprotective effect in in vitro ischemia. Proc Natl Acad Sci USA 97:10242-10247

30. Jin KL, Mao XO, Nagayama T, Goldsmith PC, Greenberg DA (2000) Induction of vascular endothelial growth factor receptors and phosphatidylinositol 3'-kinase/Akt signaling by global cerebral ischemia in the rat. Neuroscience 100:713-717

31. Joko J, Mazurek M (2004) Transcription factors having impact on vascular endothelial growth factor (VEGF) gene expression in angiogenesis. Med Sci Monit 10:RA89-RA98

32. Kilic E, Kilic U, Wang Y, Bassetti CL, Marti HH, Hermann DM (2006) The phosphatidylinositol-3 kinase/Akt pathway mediates VEGF's neuroprotective activity and induces blood brain barrier permeability after focal cerebral ischemia. FASEB J 20:1185-1187

33. Kim BK, Kim SE, Shim JH, Woo DH, Gil JE, Kim SK, Kim JH (2006) Neurogenic effect of vascular endothelial growth factor during germ layer formation of human embryonic stem cells. FEBS Lett 580:5869-5874

34. Krum JM, Mani N, Rosenstein JM (2002) Angiogenic and astroglial responses to vascular endothelial growth factor administration in adult rat brain. Neuroscience 110:589-604

35. Kuldo JM, Ogawara KI, Werner N, Asgeirsdottir SA, Kamps JA, Kok RJ, Molema G (2005) Molecular pathways of endothelial cell 
activation for (targeted) pharmacological intervention of chronic inflammatory diseases. Curr Vasc Pharmacol 3:11-39

36. Lagercrantz J, Farnebo F, Larsson C, Tvrdik T, Weber G, Piehl F (1998) A comparative study of the expression patterns for vegf, vegf-b/vrf and vegf-c in the developing and adult mouse. Biochim Biophys Acta 1398:157-163

37. Lennmyr F, Ata KA, Funa K, Olsson Y, Terent A (1998) Expression of vascular endothelial growth factor (VEGF) and its receptors (Flt-1 and Flk-1) following permanent and transient occlusion of the middle cerebral artery in the rat. J Neuropathol Exp Neurol 57:874-882

38. Liu Y, Cox SR, Morita T, Kourembanas S (1995) Hypoxia regulates vascular endothelial growth factor gene expression in endothelial cells. Identification of a 5' enhancer. Circ Res 77:638-643

39. Marti HH, Risau W (1998) Systemic hypoxia changes the organspecific distribution of vascular endothelial growth factor and its receptors. Proc Natl Acad Sci USA 95:15809-15814

40. McCloskey DP, Croll SD, Scharfman HE (2005) Depression of synaptic transmission by vascular endothelial growth factor in adult rat hippocampus and evidence for increased efficacy after chronic seizures. J Neurosci 25:8889-8897

41. Monacci WT, Merrill MJ, Oldfield EH (1993) Expression of vascular permeability factor/vascular endothelial growth factor in normal rat tissues. Am J Physiol 264:C995-C1002

42. Nag S, Eskandarian MR, Davis J, Eubanks JH (2002) Differential expression of vascular endothelial growth factor-A (VEGF-A) and VEGF-B after brain injury. J Neuropathol Exp Neurol 61:778-788

43. Nash AD, Baca M, Wright C, Scotney PD (2006) The biology of vascular endothelial growth factor-B (VEGF-B). Pulm Pharmacol Ther 19:61-69

44. Newton SS, Collier EF, Hunsberger J, Adams D, Terwilliger R, Selvanayagam E, Duman RS (2003) Gene profile of electroconvulsive seizures: induction of neurotrophic and angiogenic factors. J Neurosci 23:10841-10851

45. Nicoletti JN, Shah SK, McCloskey DP, Goodman JH, Elkady A, Atassi H, Hylton D, Rudge JS, Scharfman HE, Croll SD (2008) Vascular endothelial growth factor is up-regulated after status epilepticus and protects against seizure-induced neuronal loss in hippocampus. Neuroscience 151(1):232-241

46. Olofsson B, Pajusola K, Kaipainen A, von Euler G, Joukov V, Saksela O, Orpana A, Pettersson RF, Alitalo K, Eriksson U (1996) Vascular endothelial growth factor B, a novel growth factor for endothelial cells. Proc Natl Acad Sci USA 93:2576-2581

47. Oosthuyse B, Moons L, Storkebaum E, Beck H, Nuyens D, Brusselmans K, Van Dorpe J, Hellings P, Gorselink M, Heymans S, Theilmeier G, Dewerchin M, Laudenbach V, Vermylen P, Raat H, Acker T, Vleminckx V, Van Den Bosch L, Cashman N, Fujisawa H, Drost MR, Sciot R, Bruyninckx F, Hicklin DJ, Ince C, Gressens P, Lupu F, Plate KH, Robberecht W, Herbert JM, Collen D, Carmeliet P (2001) Deletion of the hypoxia-response element in the vascular endothelial growth factor promoter causes motor neuron degeneration. Nat Genet 28:131-138

48. Palmini A, Najm I, Avanzini G, Babb T, Guerrini R, FoldvarySchaefer N, Jackson G, Luders HO, Prayson R, Spreafico R, Vinters HV (2004) Terminology and classification of the cortical dysplasias. Neurology 62:S2-S8

49. Partanen TA, Makinen T, Arola J, Suda T, Weich HA, Alitalo K (1999) Endothelial growth factor receptors in human fetal heart. Circulation 100:583-586

50. Petrova TV, Makinen T, Alitalo K (1999) Signaling via vascular endothelial growth factor receptors. Exp Cell Res 253:117-130

51. Pietsch T, Valter MM, Wolf HK, von Deimling A, Huang HJ, Cavenee WK, Wiestler OD (1997) Expression and distribution of vascular endothelial growth factor protein in human brain tumors. Acta Neuropathol 93:109-117
52. Plate KH, Beck H, Danner S, Allegrini PR, Wiessner C (1999) Cell type specific upregulation of vascular endothelial growth factor in an MCA-occlusion model of cerebral infarct. J Neuropathol Exp Neurol 58:654-666

53. Raab S, Plate KH (2007) Different networks, common growth factors: shared growth factors and receptors of the vascular and nervous system. Acta Neuropathol 113:607-626

54. Ravizza T, Boer K, Redeker S, Spliet WG, van Rijen PC, Troost D, Vezzani A, Aronica E (2006) The IL-1beta system in epilepsyassociated malformations of cortical development. Neurobiol Dis 24:128-143

55. Ravizza T, Gagliardi B, Noe F, Boer K, Aronica E, Vezzani A (2008) Innate and adaptive immune mechanisms during epileptogenesis and spontaneous seizures: evidence from experimental models and human temporal lobe epilepsy. Neurobiol Dis 29:142160

56. Rigau V, Morin M, Rousset MC, de Bock F, Lebrun A, Coubes P, Picot MC, Baldy-Moulinier M, Bockaert J, Crespel A, Lerner-Natoli M (2007) Angiogenesis is associated with blood-brain barrier permeability in temporal lobe epilepsy. Brain 130:1942-1956

57. Rosenstein JM, Mani N, Silverman WF, Krum JM (1998) Patterns of brain angiogenesis after vascular endothelial growth factor administration in vitro and in vivo. Proc Natl Acad Sci USA 95:7086-7091

58. Roy H, Bhardwaj S, Yla-Herttuala S (2006) Biology of vascular endothelial growth factors. FEBS Lett 580:2879-2887

59. Salhia B, Angelov L, Roncari L, Wu X, Shannon P, Guha A (2000) Expression of vascular endothelial growth factor by reactive astrocytes and associated neoangiogenesis. Brain Res 883:87-97

60. Schoch HJ, Fischer S, Marti HH (2002) Hypoxia-induced vascular endothelial growth factor expression causes vascular leakage in the brain. Brain 125:2549-2557

61. Semenza GL (2000) HIF-1: using two hands to flip the angiogenic switch. Cancer Metastasis Rev 19:59-65

62. Silins G, Grimmond S, Egerton M, Hayward N (1997) Analysis of the promoter region of the human VEGF-related factor gene. Biochem Biophys Res Commun 230:413-418

63. Silvestre JS, Tamarat R, Ebrahimian TG, Le-Roux A, Clergue M, Emmanuel F, Duriez M, Schwartz B, Branellec D, Levy BI (2003) Vascular endothelial growth factor-B promotes in vivo angiogenesis. Circ Res 93:114-123

64. Simon M, Rockl W, Hornig C, Grone EF, Theis H, Weich HA, Fuchs E, Yayon A, Grone HJ (1998) Receptors of vascular endothelial growth factor/vascular permeability factor (VEGF/VPF) in fetal and adult human kidney: localization and [125I]VEGF binding sites. J Am Soc Nephrol 9:1032-1044

65. Smith PK, Krohn RI, Hermanson GT, Mallia AK, Gartner FH, Provenzano MD, Fujimoto EK, Goeke NM, Olson BJ, Klenk DC (1985) Measurement of protein using bicinchoninic acid. Anal Biochem 150:76-85 [published erratum appears in Anal Biochem 1987 May 15;163(1):279]

66. Spliet WG, Aronica E, Ramkema M, Witmer AN, Schlingemann RO, de Jong JM, Troost D (2004) Immunohistochemical localization of vascular endothelial growth factor receptors-1, -2 and -3 in human spinal cord: altered expression in amyotrophic lateral sclerosis. Neuropathol Appl Neurobiol 30:351-359

67. Sun FY, Guo X (2005) Molecular and cellular mechanisms of neuroprotection by vascular endothelial growth factor. J Neurosci Res 79:180-184

68. Sun Y, Jin K, Childs JT, Xie L, Mao XO, Greenberg DA (2004) Increased severity of cerebral ischemic injury in vascular endothelial growth factor-B-deficient mice. J Cereb Blood Flow Metab 24:1146-1152

69. Sun Y, Jin K, Childs JT, Xie L, Mao XO, Greenberg DA (2006) Vascular endothelial growth factor-B (VEGFB) stimulates neuro- 
genesis: evidence from knockout mice and growth factor administration. Dev Biol 289:329-335

70. Sun Y, Jin K, Xie L, Childs J, Mao XO, Logvinova A, Greenberg DA (2003) VEGF-induced neuroprotection, neurogenesis, and angiogenesis after focal cerebral ischemia. J Clin Invest 111:1843-1851

71. Sunderkotter C, Steinbrink K, Goebeler M, Bhardwaj R, Sorg C (1994) Macrophages and angiogenesis. J Leukoc Biol 55:410-422

72. Tham E, Gielen AW, Khademi M, Martin C, Piehl F (2006) Decreased expression of VEGF-A in rat experimental autoimmune encephalomyelitis and in cerebrospinal fluid mononuclear cells from patients with multiple sclerosis. Scand J Immunol 64:609-622

73. Thom M (2004) Recent advances in the neuropathology of focal lesions in epilepsy. Expert Rev Neurother 4:973-984

74. van Veelen CW, Debets RM, van Huffelen AC, van Emde Boas W, Binnie CD, Storm van Leeuwen W, Velis DN, van Dieren A (1990) Combined use of subdural and intracerebral electrodes in preoperative evaluation of epilepsy. Neurosurgery 26:93-101

75. van Vliet EA, da Costa Araújo S, Redeker S, van Schaik R, Aronica E, Gorter JA (2007) Long-lasting increased permeability of the blood-brain barrier may contribute to seizure progression in temporal lobe epilepsy. Brain 130:521-534

76. Vezzani A (2005) VEGF and seizures: cross-talk between endothelial and neuronal environments. Epilepsy Curr 5:72-74

77. Vezzani A, Granata T (2005) Brain inflammation in epilepsy: experimental and clinical evidence. Epilepsia 46:1724-1743

78. Wada K, Arai H, Takanashi M, Fukae J, Oizumi H, Yasuda T, Mizuno Y, Mochizuki H (2006) Expression levels of vascular endothelial growth factor and its receptors in Parkinson's disease. Neuroreport 17:705-709

79. Wang WY, Dong JH, Liu X, Wang Y, Ying GX, Ni ZM, Zhou CF (2005) Vascular endothelial growth factor and its receptor Flk-1 are expressed in the hippocampus following entorhinal deafferentation. Neuroscience 134:1167-1178

80. Witmer AN, Dai J, Weich HA, Vrensen GF, Schlingemann RO (2002) Expression of vascular endothelial growth factor receptors 1,2 , and 3 in quiescent endothelia. $\mathrm{J}$ Histochem Cytochem 50:767-777

81. Yamazaki Y, Morita T (2006) Molecular and functional diversity of vascular endothelial growth factors. Mol Divers 10:515-527 